\section{Interspecific Responses of Marigold to Manganese as Influenced by Nitrogen Source}

\author{
K.S. Reddy' and H.A. Mills \\ Department of Horticulture, University of Georgia, Athens, GA 30602
}

Additional index words. Tagetes erects, Tagetes patula, manganese toxicity, nitrate, ammonium, hydroponics

\begin{abstract}
Responses of two hydroponically grown marigold species, Tagetes erects L. 'pumpkin Crush' and T. patula L. 'Janie Yellow', to Mn concentrations of $0.5 \mathrm{mg} \cdot \mathrm{liter}^{-1}$ or 10 mg-1iter ${ }^{-1}$ with $\mathrm{KNO}_{3}$ and $\mathrm{Ca}\left(\mathrm{NO}_{3}\right)_{2}\left(\mathrm{NO}_{3}\right.$ source) or $\mathrm{NH}_{4} \mathrm{NO}_{3}$ as the $\mathrm{N}$ source were investigated. In both species, $\mathrm{Mn}$ uptake was enhanced with the $\mathrm{NO}_{3}$ source while reduced with $\mathrm{NH}_{4} \mathrm{NO}_{3}$. With $\mathrm{Mn}$ supplied at $0.5 \mathrm{mg} \cdot \mathrm{liter}{ }^{-1}$ and $\mathrm{NO}_{3}$ as the $\mathrm{N}$ source, $T$. erects absorbed twice the Mn per gram of dry matter as $T$. patula. T. erecta accumulated higher concentration of $\mathrm{Mn}$ in the shoot than in the root irrespective of the $\mathrm{N}$ source. $T$. patula accumulated higher concentration of $\mathrm{Mn}$ in the roots with the $\mathrm{NO}_{3}$ source while $\mathrm{NH}_{4} \mathrm{NO}_{3}$ shifted the Mn accumulation to the shoot. Growth of both species was suppressed with $10 \mathrm{mg} \mathrm{Mn} /$ liter and the suppression was greater with the $\mathrm{NO}_{3}$ source than with the $\mathrm{NH}_{4} \mathrm{NO}_{3}$. These results indicate an interspecific response to $\mathrm{Mn}$ concentration as well as an $\mathbf{N}$ source influence on the uptake of $\mathrm{Mn}$ in marigold grown under hydroponic conditions.
\end{abstract}

Manganese-related abnormal growth was encountered in the production of marigold, with Mn toxicity occurring more intensely in some genotypes than in others (Biernbaum et al., 1988). The reason for this differential behavior of marigold genotypes to Mn toxicity was not known. Genotypic differences to Mn toxicity were observed in other plant species and were attributed to the tolerance mechanism of shoots to high Mn concentrations and not to reduced uptake of $\mathrm{Mn}$ by plants (Horst, 1980).

Biernbaum et al. (1988) recommended NO (vs. $\mathrm{NH}_{4}$ ) fertilization as a cultural practice to reduce the uptake of $\mathrm{Mn}$ by marigold. It is generally recognized that $\mathrm{Mn}$ availability in the soil is related to soil $\mathrm{pH}$, with acidic soils having a higher concentration of $\mathrm{Mn}$ in the soil solution than alkaline soils. Since nitrate fertilization increases soil $\mathrm{pH}$, use of this $\mathrm{N}$ source should result in a decreased concentration of $\mathrm{Mn}$ in the soil solution and consequently uptake by plants. However, nitrate or $\mathrm{NH}_{4}$ influences not only the rhizosphere $\mathrm{pH}$ but also the uptake of other ions by plants (Barker and Mills, 1980), and this latter factor must also be considered independent of Mn availability to plants as a consequence of rhizosphere $\mathrm{pH}$ changes.

This study was conducted to evaluate the Mn uptake as influenced by plant species, Mn solution concentration, and $\mathrm{N}$ source in marigold grown under hydroponic conditions.

An experiment was conducted in the

Received for publication 9 July 1990 . The cost of publishing this paper was defrayed in part by the payment of page charges. Under postal regulations, this paper therefore must be hereby marked advertisement solely to indicate this fact.

'Current address: Dept. of Horticulture, Mississippi State Univ., P.O. Drawer T, Mississippi State, MS 39762. greenhouse in the spring (day/night cycle $25 \mathrm{C} /$ 20C; natural day length, $13 \mathrm{~h}$ ). Seeds of 'Pumpkin Crush' and 'Janie Yellow' marigolds (Park Seed Co., Greenwood, S. C.) were and $\mathrm{N}$ source. concentration and $\mathrm{N}$ source. germinated in perlite and after 2 weeks transferred to 15-liter nutrient solution containers (four plants per container). The nutrient solution composition was $\left(\mathrm{mg} \cdot\right.$ liter $\left.^{-1}\right): 70 \mathrm{~N}$, $20 \mathrm{P}, 81 \mathrm{~K}, 72 \mathrm{Ca}, 20 \mathrm{Mg}, 2.5 \mathrm{Fe}$ (as FeEDTA), and 0.5 each of $\mathrm{B}, \mathrm{Zn}, \mathrm{Cu}$, and Mo. Nitrogen was supplied as all nitrate [as $\mathrm{KNO}_{3}$ and $\mathrm{Ca}\left(\mathrm{NO}_{3}\right)_{2}$ ] or in a 50:50 ratio of $\mathrm{NH}_{4}$ plus $\mathrm{NO}_{3}\left(\right.$ as $\mathrm{NH}_{4} \mathrm{NO}_{3}$ ). Manganese (as $\mathrm{MnCl}_{2}$ ) was supplied at 0.5 or $10 \mathrm{mg} \cdot$ liter $^{-1}$. Each treatment was replicated three times in a randomized complete-block design. The nutrient solutions were changed weekly with evapotranspiration water losses replaced daily.

The $\mathrm{pH}$ of the fresh nutrient solutions was 5.5. The $\mathrm{pH}$ of the used nutrient solutions was measured at the end of each week. Nitrate nutrition increased the $\mathrm{pH}$, whereas $\mathrm{NH}_{4} \mathrm{NH}_{3}$ nutrition decreased the $\mathrm{pH}$. These changes were greater as the plant size increased. However, the $\mathrm{pH}$ values did not drop below 5 (with $\mathrm{NH}_{4} \mathrm{NO}_{3}$ ) or above 6 (with $\mathrm{NO}_{3}$ ) in any week.

Manganese and $\mathrm{N}$ uptake was measured weekly as the difference between initial and final concentrations of these ions in the nutrient solutions. After 5 weeks in the solution culture, the plants were harvested with roots, shoots, and flowers separated, and their dry weights determined. The plant parts were ground through a 20-mesh screen in a Wiley mill and then dry-ashed for Mn determina-

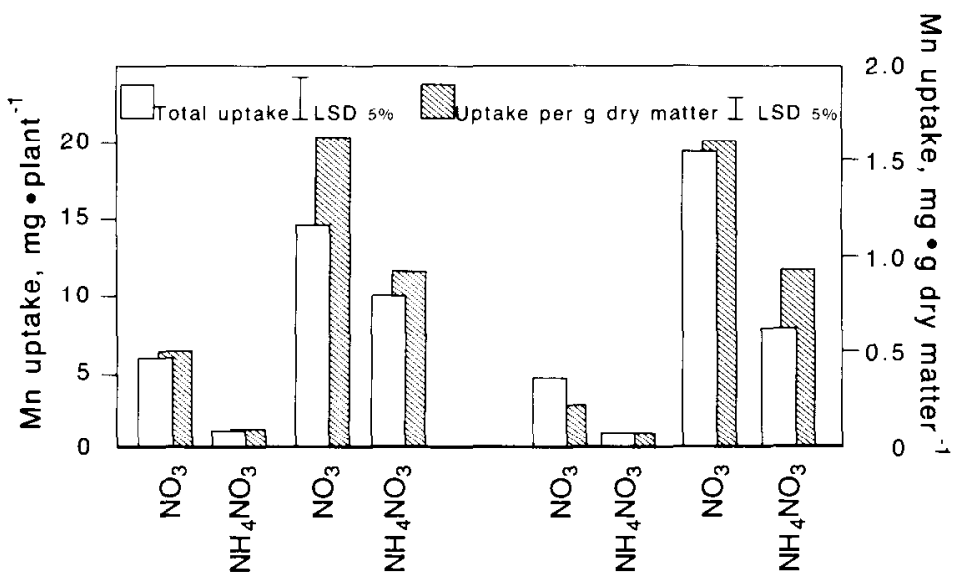

Fig. 1. Cumulative Mn uptake over 5 weeks by marigold species as influenced by Mn concentration

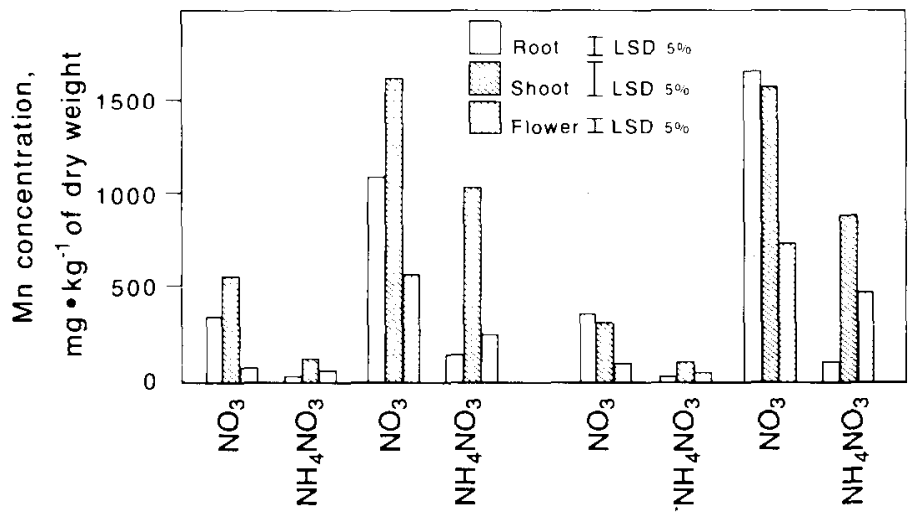

Fig. 2. Manganese concentration in plant parts of marigold species at harvest as influenced by Mn 


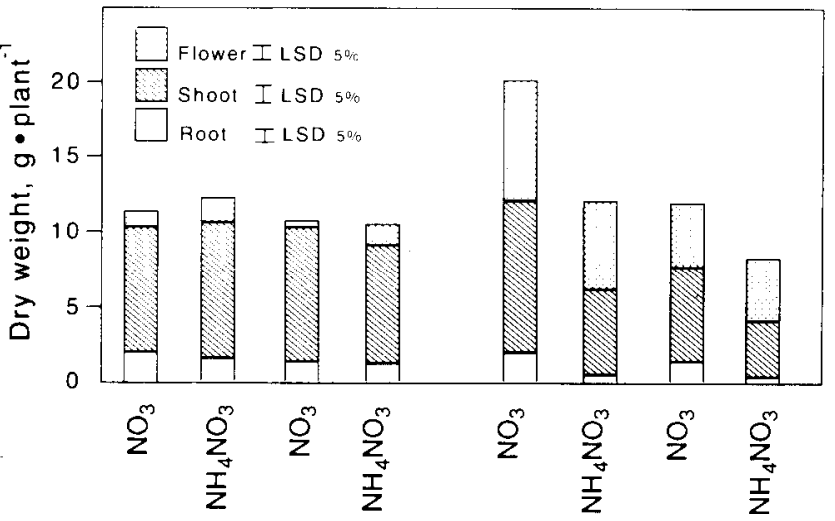

Fig. 3. Production and distribution of dry matter in marigold species as influenced by Mn concentration and $\mathrm{N}$ source.

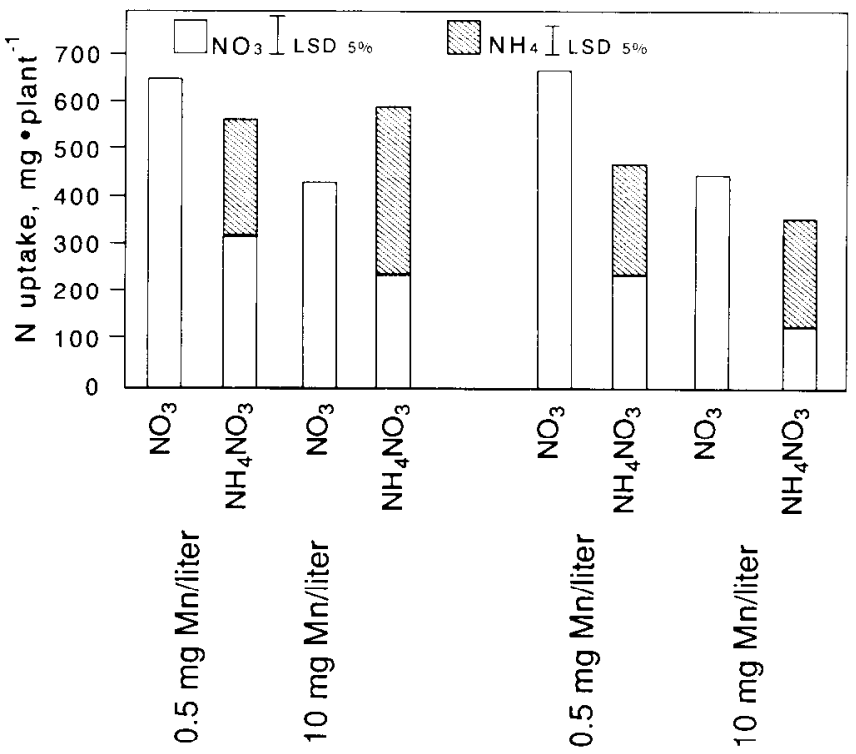

Fig. 4. Cumulative $\mathrm{N}$ uptake over 5 weeks by marigold species as influenced by Mn concentration and $\mathrm{N}$ source.

tion (Jones, 1985). Manganese in the nutrient solutions and plant tissues was determined by plasma emission spectrometry (Jones, 1985). Nitrate and $\mathrm{NH}_{4}$ in the nutrient solutions and plant tissue $\mathrm{N}$ following the Kjeldahl digestion were determined calorimetrically using an AutoAnalyzer (Jones, 1985).

The data were analyzed by analysis of variance and the treatment means were compared by least significant difference. The trends of $\mathrm{Mn}$ and $\mathrm{N}$ uptake in each week were similar throughout the experiment; therefore, only the cumulative uptake data are presented.

In both species, the $\mathrm{NO}_{3}$ source enhanced Mn uptake while $\mathrm{NH}_{4} \mathrm{NO}_{3}$ restricted $\mathrm{Mn}$ uptake (Fig. 1). When compared with the $\mathrm{NO}_{3}$ source, $\mathrm{NH}_{4} \mathrm{NO}_{3}$ resulted in Mn uptake levels that were $75 \%$ lower in both species at $0.5 \mathrm{mg} \mathrm{Mn} /$ liter. At $10 \mathrm{mg} \mathrm{Mn/liter,} \mathrm{NH}_{4} \mathrm{NO}_{3}$ resulted in $30 \%$ lower Mn uptake levels in T. erecta and $60 \%$ in T. patula compared with the $\mathrm{NO}_{3}$ source. At $0.5 \mathrm{mg} \mathrm{Mn} / \mathrm{liter}$, Mn uptake per gram of dry matter by $T$. erecta was four times higher with the $\mathrm{NO}_{3}$ source than with $\mathrm{NH}_{4} \mathrm{NO}_{3}$, while the corresponding Mn uptake by $T$. patula was two times higher. At $0.5 \mathrm{mg} \mathrm{Mn} /$ liter, when $\mathrm{NO}_{3}$ was the only $\mathrm{N}$ source, $T$. erecta absorbed twice the Mn per gram of dry matter as $T$. patula. However, this capability by $T$. erecta to take up Mn was not evident with $\mathrm{NH}_{4} \mathrm{NO}_{3}$ or even with the $\mathrm{NO}_{3}$ source at $10 \mathrm{mg} \mathrm{Mn} /$ liter.

T. erecta contained higher Mn concentration in shoots than roots, regardless of the $\mathrm{N}$ source (Fig. 2). However, Mn concentration in the roots and shoots of $T$. patula differed with the $\mathrm{N}$ source. With the $\mathrm{NO}_{3}$ source, $\mathrm{Mn}$ concentration in the roots was higher than in the shoots, while with $\mathrm{NH}_{4} \mathrm{NO}_{3} \mathrm{Mn}$ concentration was higher in the shoots. These results indicate that Mn accumulation in the shoots was influenced by the interaction of species $\times \mathrm{N}$ source. Mn concentration was higher with the $\mathrm{NO}_{3}$ source, indicating that a greater proportion of $\mathrm{Mn}$ accumulated in the roots with the $\mathrm{NO}_{3}$ only than with $\mathrm{NH}_{4} \mathrm{NO}_{3}$. The proportion of the $\mathrm{Mn}$ that accumulated in the roots more
In both species, the ratio of root : shoot than doubled between 0.5 and $10 \mathrm{mg} \mathrm{Mn} /$ liter. Thus, Mn accumulation was not restricted to the shoot alone, and with excess Mn the roots also acted as a sink. The enhanced Mn uptake with both the $\mathrm{NO}_{3}$ source and $10 \mathrm{mg} \mathrm{Mn} /$ liter resulted in the flowers also acting as a sink, with higher Mn concentrations found in the flowers.

At $10 \mathrm{mg} \mathrm{Mn} /$ liter, although typical $\mathrm{Mn}$ toxicity did not appear on either species, $>10 \%$ growth reduction was observed compared with $5 \mathrm{mg} \cdot \operatorname{liter}^{-1}$ (Fig. 3). The reduction in growth was greater with the $\mathrm{NO}_{3}$ source than with $\mathrm{NH}_{4} \mathrm{NO}_{3}$.

Both T. erecta and T. patula absorbed more $\mathrm{N}$ with the $\mathrm{NO}_{3}$ source than with $\mathrm{NH}_{4} \mathrm{NO}_{3}$ at $0.5 \mathrm{mg} \mathrm{Mn} /$ liter (Fig. 4). At $10 \mathrm{mg} \cdot$ liter $^{-1}$, T. erecta absorbed more $\mathrm{N}$ with $\mathrm{NH}_{4} \mathrm{NO}_{3}$ while $T$. patula still absorbed more $\mathrm{N}$ with the $\mathrm{NO}_{3}$ source. In both species, at $0.5 \mathrm{mg}$ $\mathrm{Mn} / \mathrm{liter}$, the uptake of $\mathrm{NH}_{4}-\mathrm{N}$ was $40 \%$ of the total $\mathrm{N}$ absorbed, but at $10 \mathrm{mg} \cdot \operatorname{liter}^{-1}$ the uptake of $\mathrm{NH}_{4}-\mathrm{N}$ increased to $60 \%$.

From these results, it is evident that variable responses to $\mathrm{Mn}$ can occur in marigold depending on the genotype and $\mathrm{N}$ source. For example, under identical growing conditions when fertilized with $\mathrm{KNO}_{3}$ and $\mathrm{Ca}\left(\mathrm{NO}_{3}\right)_{2}$, T. erecta would absorb higher $\mathrm{Mn}$ than $T$. patula.

It is also evident from these results that the $\mathrm{NO}_{3}$ source enhanced $\mathrm{Mn}$ uptake under hydroponic conditions although solution $\mathrm{pH}$ increased. This result is contrary to the situation in soils. However, Korcak (1988) noted that the effect of $\mathrm{pH}$ on $\mathrm{Mn}$ uptake is influenced by the type of growth medium, with Mn uptake increasing with increasing $\mathrm{pH}$ in solution cultures and decreasing with increasing $\mathrm{pH}$ in soils. This difference may be due to the organic matter in soils. In soils, Mn maybe complexed with soluble organic matter, which is greater at higher $\mathrm{pH}$. Hence, in soils as well as in other media amended with organic matter, $\mathrm{NO}_{3}$ nutrition and accompanying $\mathrm{pH}$ rise may increase $\mathrm{Mn}$ complexion and thus decrease Mn uptake. In contrast, in hydroponics and media without organic matter and consequently $\mathrm{Mn}$ complexation, a $\mathrm{NO}_{3}$ source may enhance, whereas $\mathrm{NH}_{4}$ may lower, Mn uptake, as observed in this experiment. The decrease in Mn uptake when $\mathrm{NH}_{4}$ was part of the $\mathrm{N}$ source may be due to the competition between both cations.

\section{Literature Cited}

Barker, A.V. and H.A. Mills. 1980. Ammonium and nitrate nutrition of horticultural crops. Hort. Rev. 2:395-423.

Biernbaum, J., W. Carlson, C. Shoemaker, and R. Heins. 1988. Low pH causes iron and manganese toxicity. Greenhouse Grower 6(3):9297.

Horst, W.J. 1980. Genotypic differences in the manganese tolerance to cowpea (Vigna unequiculata). Angew. Bet. 54:377-392.

Jones, J.B. Jr. 1985. Soil testing and plant analysis: guides to the fertilization of horticultural crops. Hort. Rev. 7:1-68.

Korcak, R.F. 1988. Nutrition of blueberry and other calcifuges. Hort. Rev. 10:183-227. 